\title{
Metformin enhances TRAIL-induced apoptosis by Mcl-1 degradation via Mule in colorectal cancer cells
}

\author{
Seong Hye Park ${ }^{1, *}$, Dae-Hee Lee ${ }^{1,2, *}$, Jung Lim Kim², Bo Ram Kim¹, Yoo Jin Na ${ }^{1}$, Min \\ Jee Jo ${ }^{1}$, Yoon A. Jeong ${ }^{2}$, Suk-Young Lee ${ }^{2}$, Sun Il Lee ${ }^{3}$, Yong Yook Lee ${ }^{4}$, Sang Cheul \\ $\mathrm{Oh}^{1,2}$ \\ ${ }^{1}$ Brain Korea 21 Program for Biomedicine Science, Korea University College of Medicine, Korea University, Seoul, Republic \\ of Korea \\ ${ }^{2}$ Division of Oncology/Hematology, Department of Internal Medicine, Korea University College of Medicine, Seoul, Republic \\ of Korea \\ ${ }^{3}$ Department of Surgery, Korea University Guro Hospital, Korea University College of Medicine, Seoul, Republic of Korea \\ ${ }^{4}$ The Korean Ginseng Research Institute, Daejeon, Republic of Korea \\ *These authors contributed equally to this work \\ Correspondence to: Sang Cheul Oh, email: sachoh@korea.ac.kr
}

Keywords: metformin, TRAIL, CRC, MCl-1, Noxa

Received: December 20, $2015 \quad$ Accepted: July 06, $2016 \quad$ Published: August 09, 2016

\section{ABSTRACT}

Metformin is an anti-diabetic drug with a promising anti-cancer potential. In this study, we show that subtoxic doses of metformin effectively sensitize human colorectal cancer (CRC) cells to tumor necrosis factor (TNF)-related apoptosis-inducing ligand (TRAIL), which induces apoptosis. Metformin alone did not induce apoptosis, but significantly potentiated TRAIL-induced apoptosis in CRC cells. CRC cells treated with metformin and TRAIL showed activation of the intrinsic and extrinsic pathways of caspase activation. We attempted to elucidate the underlying mechanism, and found that metformin significantly reduced the protein levels of myeloid cell leukemia 1 (Mcl-1) in CRC cells and, the overexpression of Mcl-1 inhibited cell death induced by metformin and/or TRAIL. Further experiments revealed that metformin did not affect mRNA levels, but increased proteasomal degradation and protein stability of Mcl-1. Knockdown of Mule triggered a significant decrease of $\mathrm{Mcl}-1$ polyubiquitination. Metformin caused the dissociation of Noxa from Mcl-1, which allowed the binding of the BH3-containing ubiquitin ligase Mule followed by Mcl-1ubiquitination and degradation. The metformin-induced degradation of $\mathrm{Mcl}-1$ required E3 ligase Mule, which is responsible for the polyubiquitination of Mcl-1. Our study is the first report indicating that metformin enhances TRAIL-induced apoptosis through Noxa and favors the interaction between $\mathrm{Mcl}-1$ and Mule, which consequently affects $\mathrm{Mcl}-1$ ubiquitination.

\section{INTRODUCTION}

Colorectal cancer (CRC), both the third most common form of cancer and the third leading cause of cancerrelated death worldwide, can attribute its effect in part to the metastases of its parent tumor [1]. Numerous studies have recently made remarkable advances in the search for a cure for metastatic CRC. For instance, the addition of irinotecan and oxaliplatin to 5-fluorouracil (5-FU) increased the median overall survival of 1 year [2]. Median overall survival was also increased by nearly a factor of two to
20 months when monoclonal antibody therapies such as cetuximab and bevacizumab were used [3-5]. Despite these advances, there remains a lack of effective drugs to improve overall survival in patients with CRC. Therefore, development of new therapies for metastatic CRC is urgent.

Tumor necrosis factor (TNF)-related apoptosisinducing ligand (TRAIL), a death ligand and a promising anticancer drug, is a member of the TNF- $\alpha$ superfamily that binds to the death receptors TRAIL-R1 (DR4) $[6,7]$ and TRAIL-R2 (DR5) [8,9]. While TRAIL generally does not induce normal primary cell death, TRAIL-mediated 
death of tumor cells occurs via extrinsic and intrinsic celldeath signaling pathways [10]. In the extrinsic pathway, DR-mediated apoptosis occurs when TRAIL binds to DRformed trimers of the TRAIL receptors, adaptor proteins, Fas-associated protein with death domain (FADD), and caspase-8, to form the death-inducing signaling complex (DISC) during cell death. The activation of caspase- 8 leads quickly to the formation of caspase-3 (activation form), which consequently induces cancer cell apoptosis. The intrinsic pathway is also called the mitochondriadependent apoptosis pathway. Previous studies show that TRAIL-induced cell death can be promoted by combinational treatment with various anticancer drugs at minimal toxic doses in tumor cells [11-13]. Recent reports, however, indicate that various types of cancers are resistant to TRAIL [14]. Therefore, treatment with TRAIL alone may be insufficient to overcome resistance. Thus, understanding the roles that TRAIL play and the discovery of effective sensitizers for TRAIL-mediated cancer therapy are the major challenges for the development of novel therapeutic strategies for cancer treatment.

While promising results have been reported in Chinese phase III clinical trials in which TRAIL has been used as an anti-cancer therapy, resistance to TRAILinduced apoptosis remains a main obstacle in its future clinical application. Many recent reports have focused on improving TRAIL sensitization as a way to mediate tumor cell death. Using this strategy, several novel anticancer drugs that are capable of increasing sensitization to TRAIL have been developed. For instance, wogonin, capsaicin, verrucarin A, curcumin, epigallocatechin gallate, and resveratrol, among others, have been reported to sensitize tumor cells to TRAIL-induced cell death, mostly through the cell surface receptor pathway via upregulation of DR5/DR4 through c-FLIP [15-20]. Studies have also showed that TRAIL-induced cell death can be regulated via the intrinsic pathway. By inhibiting two antiapoptotic proteins, Bcl-2 and Bcl-XL, or by increasing the expression of pro-apoptotic proteins Bad, Bax, Bim, and Bcl-xs, the sensitivity of many cancers to TRAIL treatments can be enhanced [20].

In addition, resistance to TRAIL among different types of cancer poses a major obstacle to effective therapy $[21,22]$. Therefore, scientists are in search for compounds that sensitize tumor cells to TRAIL and reverse resistance in tumor cells. This line of inquiry is important because, while approximately $60 \%$ of human tumors have been found to be TRAIL-resistant, the mechanism of resistance is poorly understood [23-26].

In the current study, we sought to assess the possible sensitizing effect of metformin on TRAIL-mediated cell death in CRC cells. In recent studies, diabetic patients receiving metformin (Figure 1A), a commonly used medication to lower blood glucose [27, 28], had decreased cancer mortality and a reduced risk of developing cancer [29-32]. Moreover, metformin sensitizes human cancer cells to classical anti-cancer agents, such as dasatinib, paclitaxel, and aspirin [33-35]. In preclinical studies, metformin inhibited proliferation, invasion, and migration of pancreatic cancer cells [36, 37] while it improved the survival outcomes of patients with $\mathrm{CRC}$ and diabetes in previous studies [38]. Notably, for the first time, our data shows that combining TRAIL and low doses of nonapoptosis-inducing metformin enhance apoptosis in human CRC cell lines. We also present the first evidence that metformin upregulates Bax and downregulates Mcl-1 as well as synergistically increases TRAIL-mediated cell death in human CRC cell lines.

\section{RESULTS}

\section{Combination of metformin and TRAIL synergistically enhances CRC cell death, but not that of normal primary colon cells}

Metformin has been previously reported to induce apoptosis in several cell types such as human cervical cancer, human ovarian, human leukemia, and human CRC [39-42]. Before investigating the effect of combined treatment with metformin and TRAIL on viability of CRC cells, we evaluated whether metformin alone induces cell death. CRC cells were exposed to $2.5-10 \mathrm{mM}$ metformin for $24 \mathrm{~h}$. Here, we found that metformin-induced cell death in a dose-dependent manner (Figure 1B). Cancer cell lines displayed various levels of sensitivity, but normal primary colon cells (FHC) were resistant to the drug. In normal colorectal cells, minimal cytotoxicity (7\% killing) was observed at a high dose $(10 \mathrm{mM})$ of metformin, while in the CRC cell lines, sensitivity was observed even at $2.5 \mathrm{mM}$. The effect of treatment with a combination of metformin and TRAIL was investigated in several CRC cell lines as well as FHC cells. Cytotoxicity was induced by TRAIL alone, in FHC cells in a dose-dependent manner (Figure 1C). Cytotoxicity was significantly enhanced by combined treatment with metformin and TRAIL in TRAIL-sensitive HCT116 cells and TRAIL-resistant DLD-1, HT29, and Colo205 cells (Figure 1E), but not in normal primary colon cells (FHC) (Figure 1D). These results suggest that the sensitizing regimen of metformin plus TRAIL may be selectively toxic to CRC cells.

\section{Metformin facilitates TRAIL-induced apoptosis in CRC cells through activation of extrinsic and intrinsic pathway}

We further investigated the synergistic interactions between metformin and TRAIL. First, the effect of metformin in combination with TRAIL on DLD-1 cell morphology was examined and photographed under a light microscope. After the application of TRAIL or metformin in combination with TRAIL, as shown in Figure 2A, cell morphology changed significantly when compared 
to control cells or cells treated with only metformin. Apoptotic cell death with morphological characterstics such as nuclear condensation, cell shrinkage, and blebbing was observed. Cells with morphological changes were counted and statistical significance was calculated (Figure 2A). Additionally, we investigated the longterm effect on clonogenic survival in a cell culture of metformin and TRAIL combination. The metformin and TRAIL combination was much more potent than either agent alone in inhibiting colony formation, in agreement with the apoptosis study. In fact, almost all colonies were eliminated, although metformin or TRAIL alone inhibited the formation and growth of colonies only partially (Figure 2B). Thus, we found that combined treatment with metformin and TRAIL synergistically induced cell death in contrast to metformin or TRAIL alone in CRC cell lines (Figure 1D). We also employed an Annexin V assay, PARP-1 cleavage assay, and cleavage of caspase $8 / 9$ to clarify whether the effect of metformin on TRAILmediated cell death was related to apoptosis. As shown in Figure 2C and 2D, we found that, while TRAIL induced apoptosis, metformin increased TRAIL-induced apoptosis in CRC cells. Furthermore, data from biochemical analysis show that, in DLD-1 cells, metformin substantially promoted TRAIL-induced activation of caspase-3, -8, and -9 , leading to increased PARP cleavage (Figure 2E). We also used pretreatment with z-VAD-fmk, a pan-caspase inhibitor, to determine that combined treatment with metformin and TRAIL significantly attenuated PARP cleavage (Figure 2F). These results show that increased apoptosis produced by metformin begins through an elevation of the extrinsic and intrinsic pathways.

\section{Mcl-1 is important for the sensitizing effect of metformin on TRAIL-induced apoptosis of CRC cells}

We investigated whether the sensitizing effect of metformin was similar to that produced by TRAIL when binding to death receptors: activation of the apoptotic signaling pathway via cleavage of caspases and inactivation of anti-apoptotic proteins [6]. We found no change either in the caspase inhibitor protein family members such as survivin, XIAP, and Bcl-XL, or in the Bcl-2 family members such as Bax, and Bcl-2. Death receptors, such as DR4 and DR5, were also unaffected during metformin treatment in DLD-1 cells, as shown in Figure 3A. But, in contrary to these proteins, the level of Mcl-1 decreased in a dose-dependent manner (Figure 3A). This observation was also true in HT29, Colo205, HCT116, and SNU C2A CRC cell lines (Figure 3B). Therefore, we studied the role of Mcl-1 by using recombinant DNA technology. Specifically, we made stable cell using Mcl-1 cDNA expression vector in DLD-1 cells. As shown in Figure 3C, DLD-1 potentiated TRAIL-induced cell death in non-treated cells. However, over-expression of Mcl-1 inhibited DLD-1's sensitizing effect on TRAIL-induced cell death. Further, knockdown of Mcl-1 by silencing RNA elevated TRAIL-induced cell death (Figure 3D), indicating that, in CRC cells, the sensitizing effect of metformin occurs through downregulation of Mcl-1 levels.

\section{Metformin induces Mcl-1 degradation via the ubiquitin-proteasome signaling pathway}

Next, we investigated whether metformin increased or decreased the level of apoptotic regulatory molecules. As shown in Figure 3A, no significant alterations in levels of the detected apoptotic regulatory proteins were observed, although the expression of Mcl-1 decreased in a dose-dependent manner in the metformin-treated cells within 16 h (Supplementary Figure S1). Therefore, we examined whether metformin modulates Mcl-1 mRNA expression. However, metformin does not affect Mcl1 mRNA transcription level (Figure 4A and 4B). When DLD-1 cells were or were not exposed to metformin in the presence of $10 \mu \mathrm{g} / \mathrm{ml}$ cyclohexamide (CHX) for the indicated time periods, metformin decreased the Mcl-1 protein stability in DLD-1 cells (Figure 4C). Consistently, in the presence of $\mathrm{CHX}$, the rate of degradation of Mcl-1 was significantly greater in metformin-treated cells than in non-treated ones. These results show that metformin decreases Mcl-1 levels through activation of the ubiquitin-proteasome-dependent pathways. Also, several studies have proven that the degradation of Mcl-1 is generally regulated by the ubiquitin-proteasome pathway [43]. Therefore, we investigated whether metformin also modulates Mcl-1 expression via the ubiquitin-proteasome pathway. First, we investigated the effect of the proteasome inhibitor (MG132) on metformininduced Mcl-1 degradation. As shown in Figure 4D and 4E, MG132 significantly inhibited the metformininduced down-regulation of Mcl-1. These results indicate that metformin-induced Mcl-1 degradation is mainly ubiquitin-dependent; however, ubiquitin-independent pathways may also be related to the degradation of Mcl-1. To investigate the pathway of Mcl-1 degradation, we also examined whether Mcl-1 participated in mitogen-activated protein kinase (MAPK) activation in the metformin-treated cells. We found that the MAPK inhibitor (PD098059) did not block Mcl-1 decrease in the metformin-treated cells (Supplementary Figure S1). These data show that the decrease of Mcl-1 plays an important role in metformininduced TRAIL sensitization.

\section{Metformin enhances interaction between Mcl-1 and Mule in DLD-1 cells}

We next investigated facilitators of Mcl-1 ubiquitination and degradation in CRC cells. Mule, also known as E3 ligase, which targets proteins for degradation, 
A<smiles>CN(C)C(=N)NC(=N)N</smiles>

C

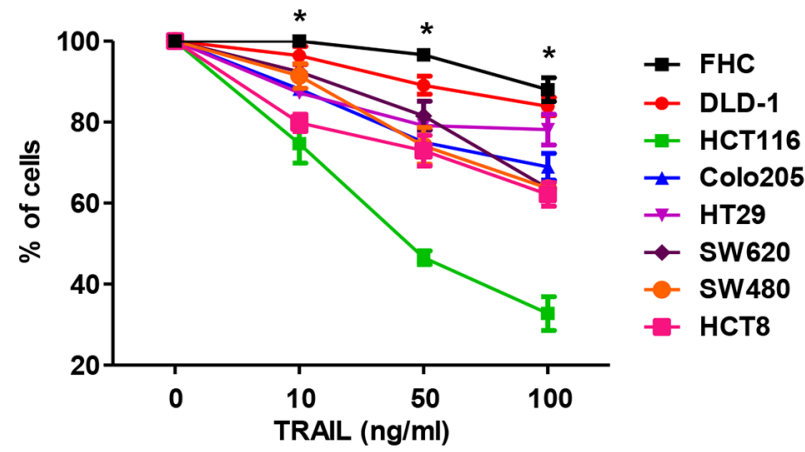

E

DLD-1

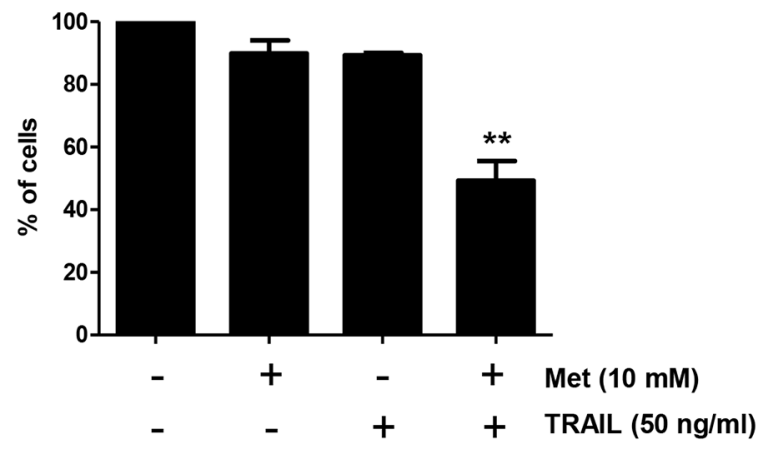

HT 29

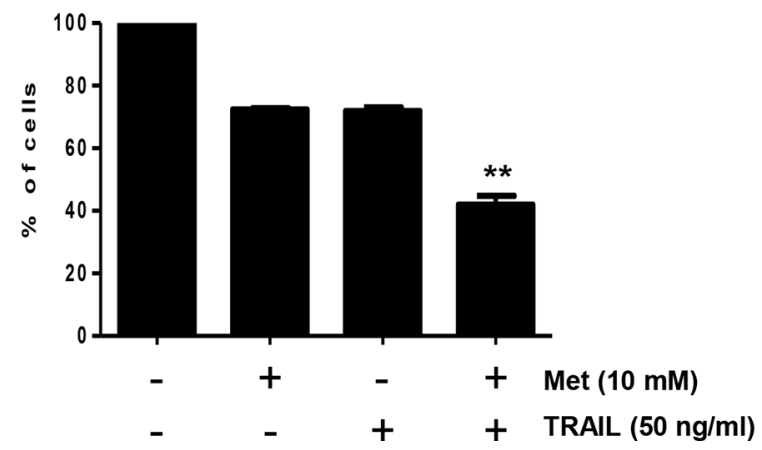

B

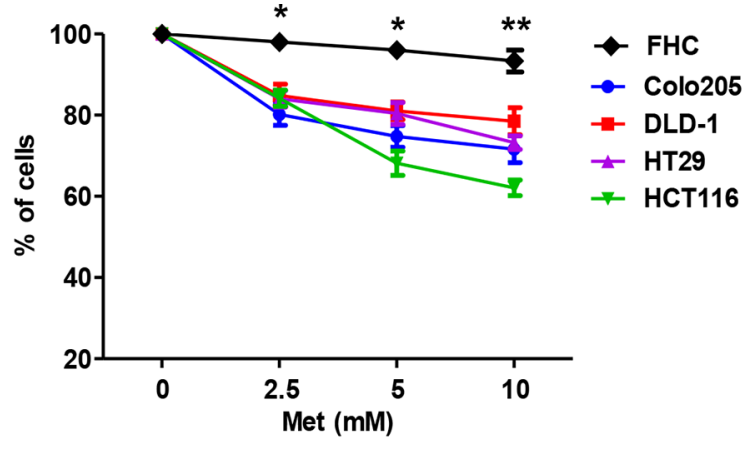

FHC

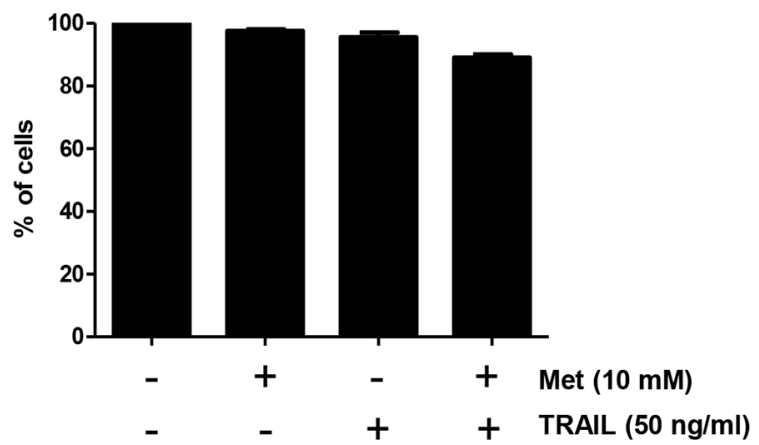

HCT116

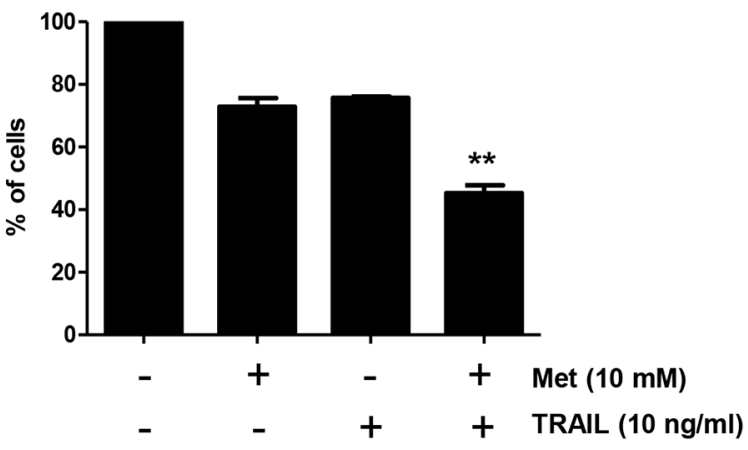

Colo205

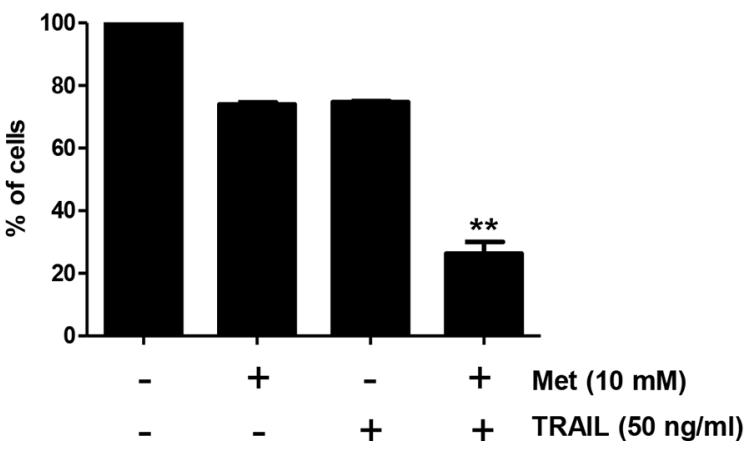

Figure 1: Metformin significantly increased TRAIL-induced cytotoxicity of human CRC cell lines. (A) The structure of metformin. Effects of metformin (B) and TRAIL (C) alone, or a combination treatment of metformin and TRAIL (D, E) on cytotoxicity of human CRC cell lines (mean $\pm \mathrm{SD}, n=3$ ). Cells were treated with DMSO (sham control) or various concentrations $(0-10 \mathrm{mM})$ of metformin for $20 \mathrm{~h}$. Cells were incubated in the presence or absence of TRAIL (10 or $50 \mathrm{ng} / \mathrm{ml})$ and/or metformin (10 mM) for $24 \mathrm{~h}$. Experiments were performed at least three times. Error bars represent standard error of the mean (SEM) from three separate experiments. Some error bars are too small to be seen. Asterisk * or ** represents a statistically significant difference between FHC and cancer cells at $p<0.05$ or $p<0.01$, respectively. 
A

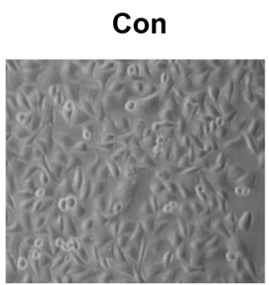

TRAIL

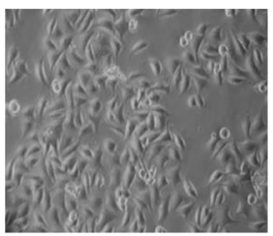

\section{C}

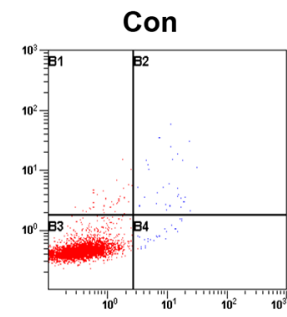

TRAIL

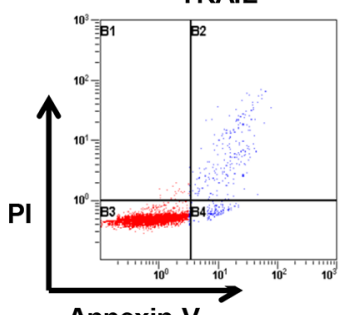

Annexin V

E

$$
\begin{array}{llll}
- & + & + & \text { Met }(10 \mathrm{mM}) \\
- & - & + & +
\end{array}
$$

18

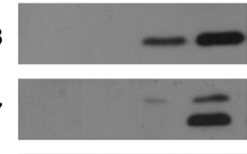

37

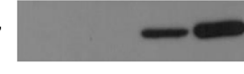

89

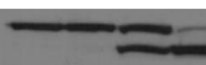

42

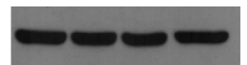

Met

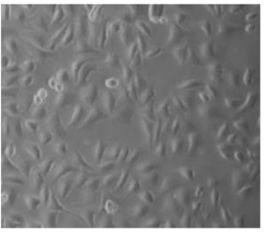

Met + TRAIL
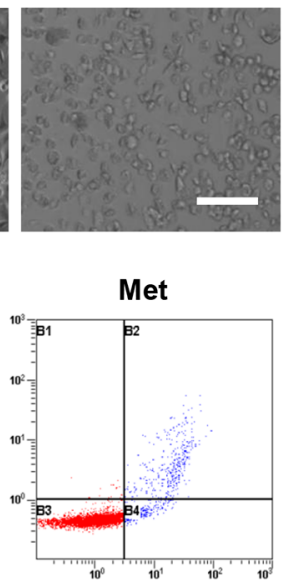

Met + rnAlL

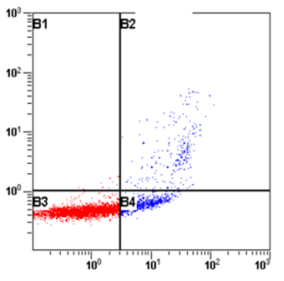

c-Caspase8

c-Caspase 3

c-Caspase9

PARP-1

$\beta$-actin
B
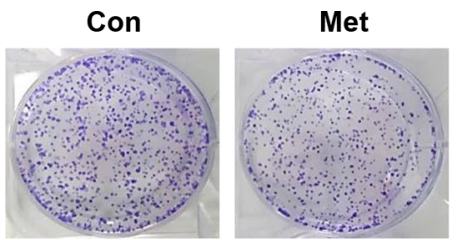

TRAIL

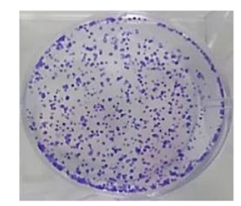

Met + TRAIL

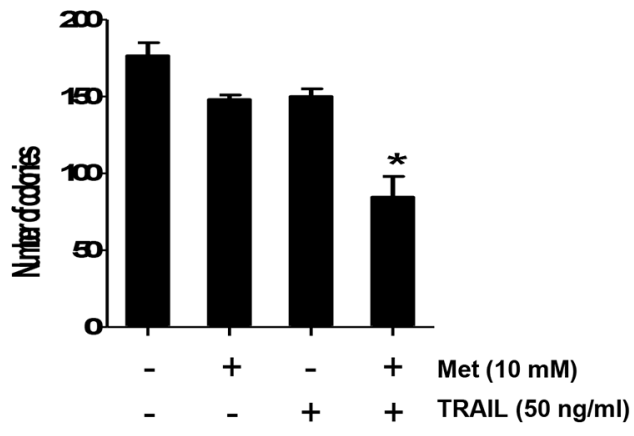

D

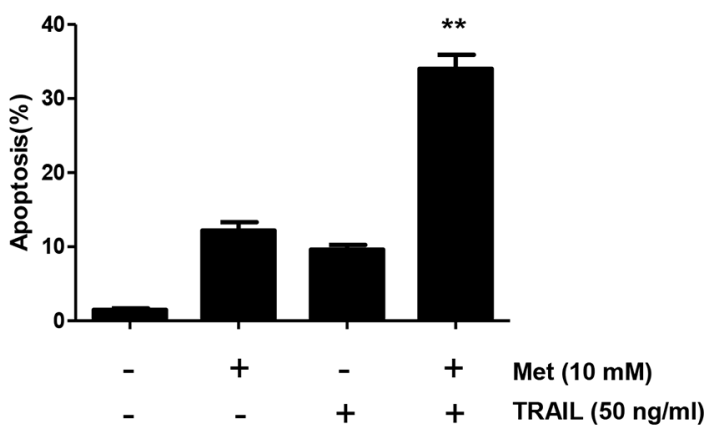

F

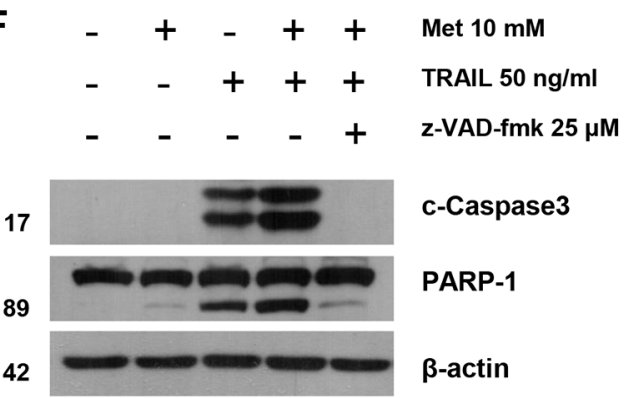

Figure 2: Sensitizing effect of metformin in TRAIL-induced apoptosis in human CRC cells. (A) Cells were treated with metformin alone, TRAIL alone, or metformin in combination with TRAIL for $24 \mathrm{~h}$. Cell morphology was examined under a light microscope. Scale bar: $100 \mu \mathrm{m}$. (B) DLD-1 cells plated in 6-well cell culture plates were treated with $10 \mathrm{mM}$ metformin, $50 \mathrm{ng} / \mathrm{ml}$ TRAIL, or their combination. The same treatments were repeated every three days. After 12 days, the plates were stained for cell colonies with crystal violet dye, and photographs of colonies taken using a digital camera. (C and D) The cells were stained with annexin V and propidium iodide (PI), followed by FACS analysis. Error bars represent standard error of the mean (SEM) from three separate experiments. Asterisk * or ** represents a statistically significant difference between treated cells and untreated control cells at $p<0.05$ or $p<0.01$, respectively. (E) Lysates containing equal amounts of protein $(20 \mu \mathrm{g})$ were separated by SDS-PAGE and immunoblotted with anti-PARP-1, anti-cleaved caspase-8, anti-cleaved caspase-9, or anti-cleaved caspase-3 antibody. (F) Cells were pretreated with $25 \mu \mathrm{M} \mathrm{z-VAD-fmk} \mathrm{for} 30$ min and further treated with metformin $(20 \mathrm{~h})+$ TRAIL ( $4 \mathrm{~h})$ for $24 \mathrm{~h}$. Lysates from cytosolic fractions containing equal amounts of protein $(20 \mu \mathrm{g})$ were separated by SDS-PAGE and immunoblotted with anti-cleaved caspase-3 and anti-PARP-1 antibody. Actin was used to confirm the equal amount of proteins loaded in each lane. 
has been characterized for Mcl-1. We investigated the expression of Mule by western blot analysis in CRC cells. Mule was universally expressed in DLD-1 cells. While ubiquitination of Mcl-1 decreased in CRC cells, Mule was universally expressed or induced by metformin (data not shown). Therefore, we investigated the interaction between Mcl-1 and Mule by immunoprecipitation assays; immunoprecipitating Mule from metformin-treated cell lysates of DLD-1 cells and immunoblotting with Mcl-1 antibody. We found enhanced Mcl-1 and Mule interaction in metformin-treated cells (Figure 5A and 5B). We confirmed this prolonged interaction between Mule and Mcl-1 in metformin-treated DLD-1 cells (Figure 5C) by immunoprecipitating Mule and blotting for Mcl-1. As a further test, we knocked down Mule expression with silencing RNA. DLD-1 cells treated with either control silencing RNA or Mule silencing RNA were incubated with metformin. The apoptotic index was then analyzed with the trypan blue assay. We found the apoptotic index of these cells significantly decreased through inhibition of Mule levels by silencing RNA treatment (Figure 5D). Our results indicate that decreased ubiquitination and degradation of Mcl-1 in CRC cells may result from the interaction among metformin, Mule, and Mcl-1.

\section{The E3 ligase Mule is required for proteasomal degradation of Mcl-1 induced by Noxa}

Among the E3 ubiquitin ligases related to Mcl-1 ubiquitination, Mule is particularly involved in the regulation of Mcl-1. Hence, we investigated the interaction between Mcl-1 and Mule in DLD-1 cells with knockdown of Noxa. First, we confirmed that metformin induces increased Bim, Puma, and Noxa expression. As shown in Figure 6A, there was no change during metformin treatment in DLD-1 cells, and in Mcl-1 degradationrelated protein members such as Bim, Puma, and Noxa. Even though the Noxa-Mcl-1 interaction was weak during base cases, this interaction increased intensely after the metformin treatment (Figure 6B). We repeated the immunoprecipitation experiments after knockdown of Noxa by silencing RNA to determine the function of Noxa in the Mule/Mcl-1 interaction. In these experiments, the interactions between Mcl-1's and Mule's were decreased and Mcl-1 polyubiquitination was inhibited by Noxa silencing (Figure 6C). Next, we analyzed the presence of higher molecular weight forms of Mcl-1 to determine if Noxa affects Mcl-1 ubiquitination. We found that knockdown of Noxa triggered a significant decrease in Mcl-1 polyubiquitination (Figure 6D). These data show that Noxa enhances the interaction between Mcl-1 and Mule and as a result, Noxa inhibits degradation by ubiquitin.

\section{DISCUSSION}

In this study, we first demonstrated that combination treatment using metformin and TRAIL synergistically inhibited proliferation of and induced apoptosis in human CRC cell lines, in addition to reducing the expression of Mcl-1, p-JAK2, and p-STAT3 (Supplementary Figure S1). Compared to the individual agents, the metformin and TRAIL combination significantly inhibited colony formation in and migration of CRC cells, as well as significantly decreased $\mathrm{Mcl}-1$ and Bcl-2 (anti-apoptotic proteins), and increased Bim and Puma (pro-apoptotic proteins) (Supplementary Figure S1).

Previous studies have demonstrated that Mcl-1 protein has a critical role in the anti-apoptotic system in CRC cells. Lee et al. [44] showed that tumor specimens overexpressed Mcl-1 in CRC patients. We found that metformin increased Mcl-1 degradation via ubiquitin and induction of cell death by downregulating STAT3 in CRC cells. In addition, higher apoptosis induction was observed when Mcl-1 was directly knocked down by silencing RNA for Mcl-1 or indirectly by inhibiting pERK1/2 (Figure 4B). Our data are consistent with those of a number of reports, which show that drugs such as bortezomib, Obatclax (a Bcl-2 inhibitor), and irinotecan downregulated $\mathrm{Mcl}-1$ to induce apoptosis in CRC cells [45-47]. Mcl-1 is also an anti-apoptotic protein known to be degraded via the ubiquitinationproteasome pathway [48]. Glycogen synthase kinase $3(\mathrm{GSK} 3 \beta)$ is a key regulator in tumorigenesis and mediates phosphorylation of Mcl-1 at Ser159 [49, 50]. As a result, GSK3 $\beta$ can be associated with $\beta$-transducin repeat-containing protein $(\beta-\mathrm{TrCP})$ or F-box/WD repeatcontaining protein 7 (FBXW7) (E3-ubiquitin ligases), resulting in Mcl-1 degradation [49, 51, 52]. Therefore, GSK $3 \beta$ plays a critical role in the negative regulation of Mcl-1 stability. We showed that metformin did not inhibit GSK3 $\beta$ phosphorylation in a dose-dependent manner (Supplementary Figure S1). In the present study, we showed that metformin decreased Mcl-1 levels, which may indicate a major event in increasing the synergism with TRAIL in dying CRC cells. This event likely occurs at the post-translational level via reaction of enzymes that regulate Mcl-1 [53]. The data presented here also indicate that metformin regulates Mcl-1 expression by stimulating proteasome-mediated degradation. Furthermore, the decrease of Mcl-1 occurred without regard to change in Mcl-1 mRNA transcriptional levels (Figure 4A and 4B). This finding is important because Mcl-1 levels are related to initial tumor relapse and shorter survival rate in patients with CRC [44]. In addition, high levels of cellular antiapoptotic proteins have been hypothesized to be due to TRAIL resistance in numerous types of cancer. Notably, 
A

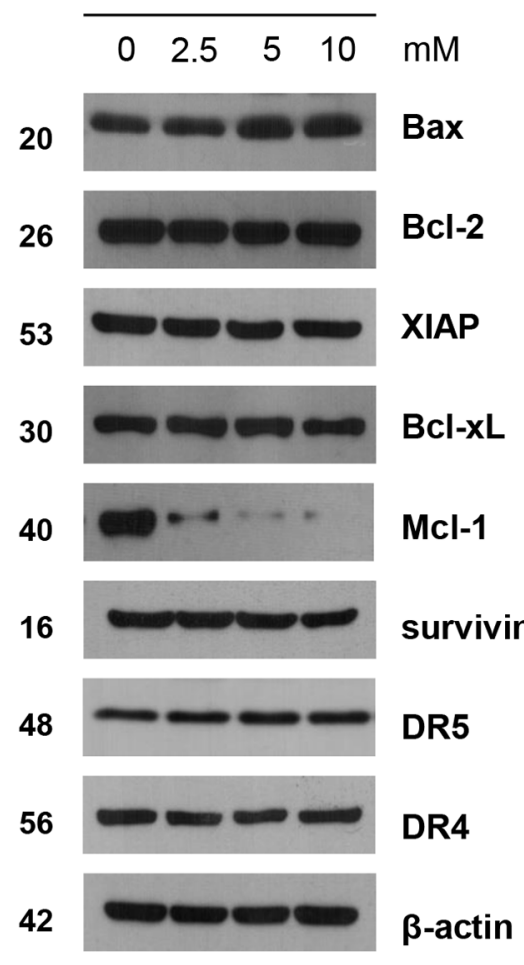

B

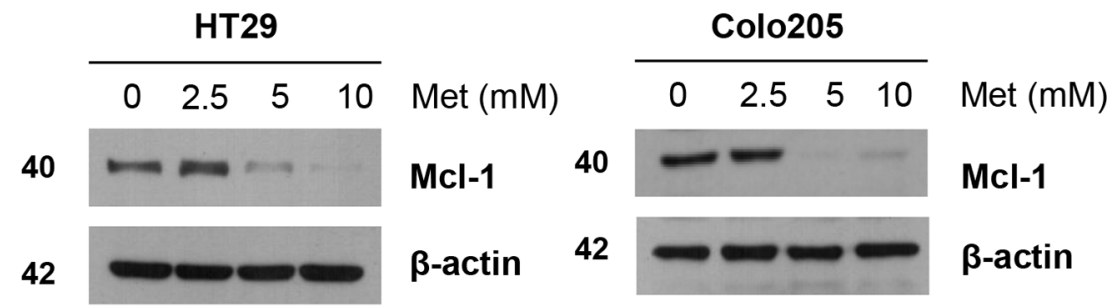

\section{C}

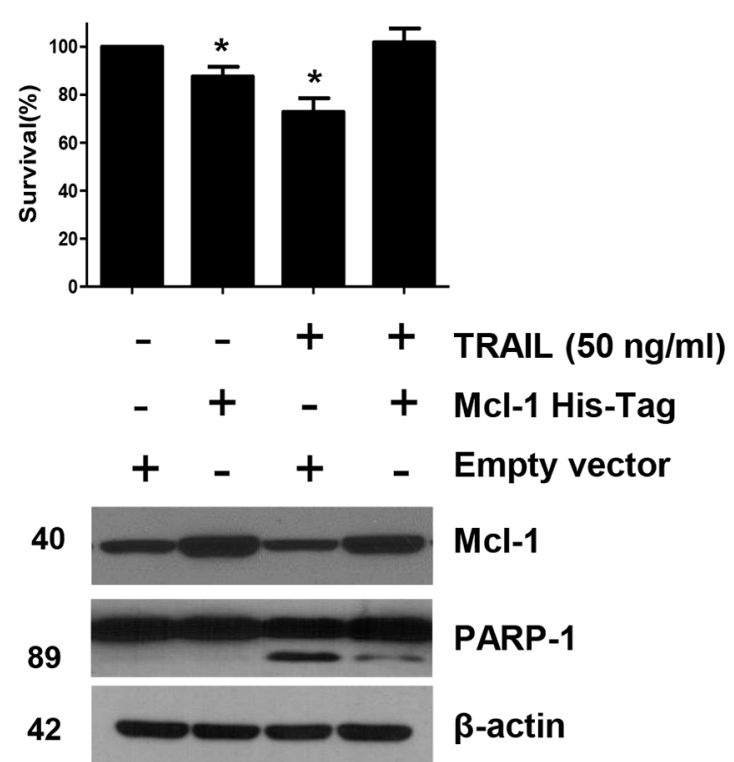

\section{HCT116}

$\begin{array}{llll}0 & 2.5 & 5 & 10\end{array}$

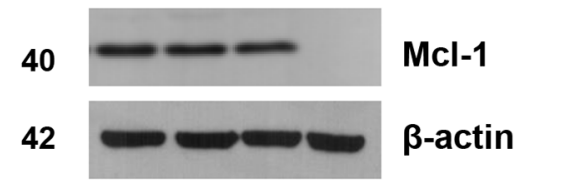

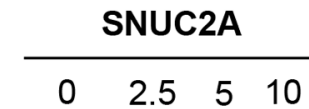

Met (mM)

40

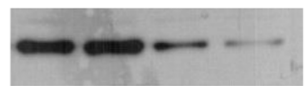

$\mathrm{Mcl}-1$

42

\section{$\beta$-actin}

Figure 3: The down-regulation of Mcl-1 by metformin is associated with the induction of TRAIL-mediated apoptosis. (A) DLD-1 cells were treated with the indicated concentrations of metformin for $20 \mathrm{~h}$. The protein expression levels of survivin, Mcl-1, XIAP, Bcl-2, Bcl-xL, Bax, DR4, DR5, and actin were determined by western blotting. (B) HT29, Colo205, HCT116, and SNU C2A cells were treated with indicated metformin doses $(0,2.5,5$, and $10 \mathrm{mM})$ for $20 \mathrm{~h}$. Cell lysates were analyzed by western blotting using anti-Mcl-1 antibody. (C) Empty vector (control) or Mcl-1 stably over-expressing DLD-1 cells (lower panel) were treated with TRAIL for 4 h. Survival was analyzed by trypan blue assay (upper panel). Densitometry analysis of the bands from cleaved PARP-1 or Mcl-1 was performed (lower panel). Error bars represent standard error of the mean (SEM) from three separate experiments. Asterisk * represents a statistically significant difference between TRAIL treated on empty vector transfected cells and TRAIL treated on Mcl-1-His vector transfected cells at $p<0.05$. (D) Mcl-1 was silenced by Mcl-1 siRNA in DLD-1 cells (lower panel). The cells were then treated with TRAIL for $4 \mathrm{~h}$ followed by trypan blue (upper panel). Results shown are representative of three independent experiments. Error bars represent standard error of the mean (SEM) from three separate experiments. Asterisk * represents a statistically significant difference between TRAIL + siCon-treated cells and TRAIL + siMcl-1-treated cells at $p<0.05$. 
increased Mcl-1 levels have been shown to inhibit TRAILinduced CRC cell death, while a decrease in Mcl-1 increased TRAIL-induced apoptosis in CRC cells [54]. This suggests that overexpression of $\mathrm{Mcl}-1$ could reduce the effect of apoptotic stimuli such as TRAIL in inducing cell death, while decreases in Mcl-1 have been associated with enhanced cytotoxicity of TRAIL [55]. This finding is consistent with other reports of inhibition of Mcl-1 by using metformin, further emphasizing the crucial role of Mcl-1 in metformin-induced apoptosis.

Overexpression of Mcl-1 has been found to be an indicator of tumor progression and poor outcomes in
A

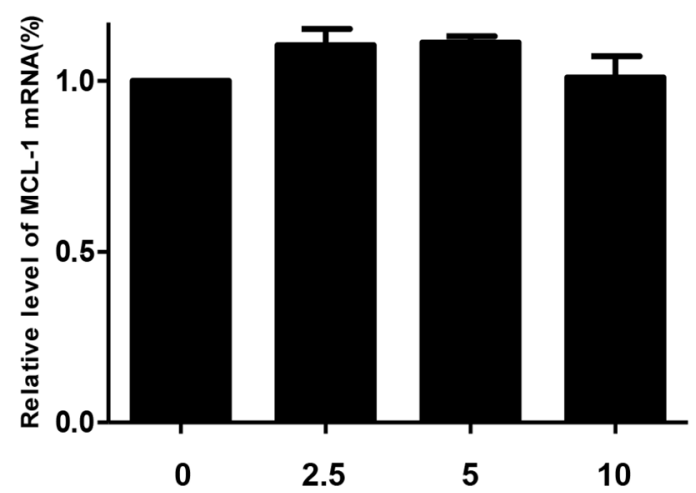

C

\section{$\mathrm{CHX}(10 \mu \mathrm{g} / \mathrm{ml})$} CHX + Metformin (10 mM)

$\begin{array}{llll}0 & 15 & 30 & 60\end{array}$

$\min$

40

42

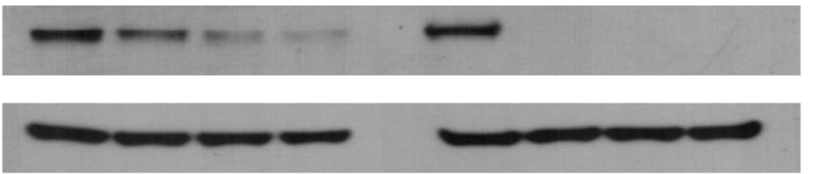

Mcl-1

B

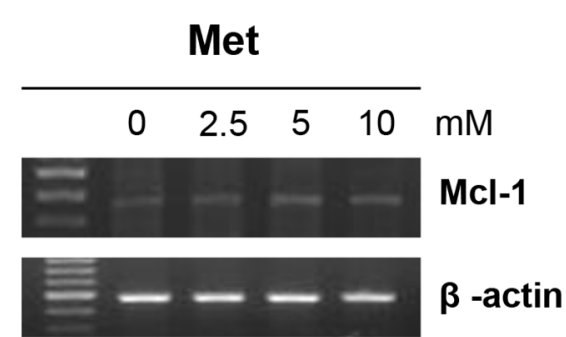

D

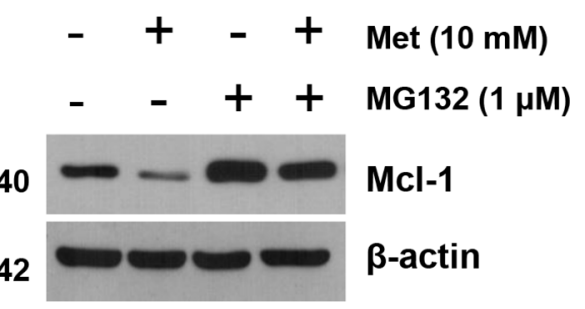

E

$\beta$-actin

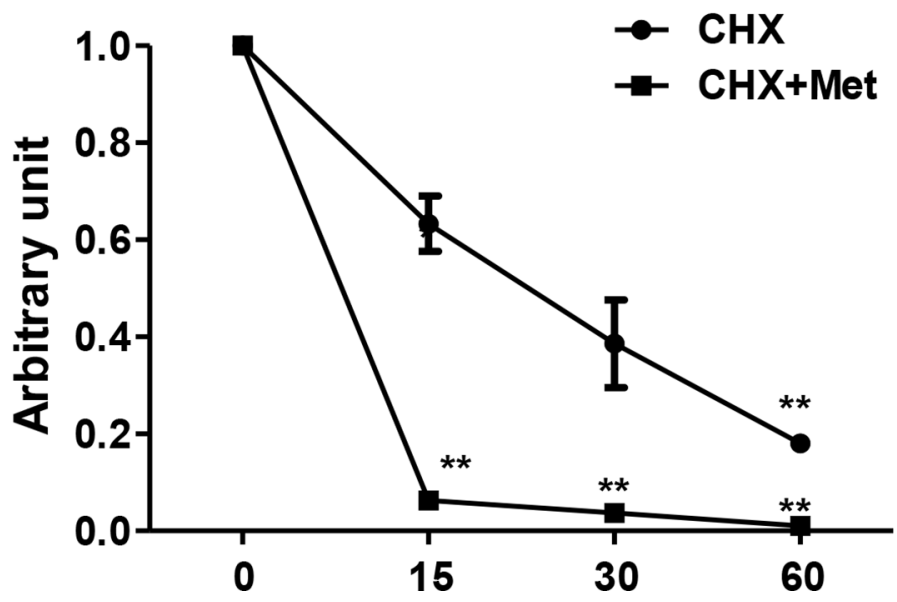

IgG Con Met

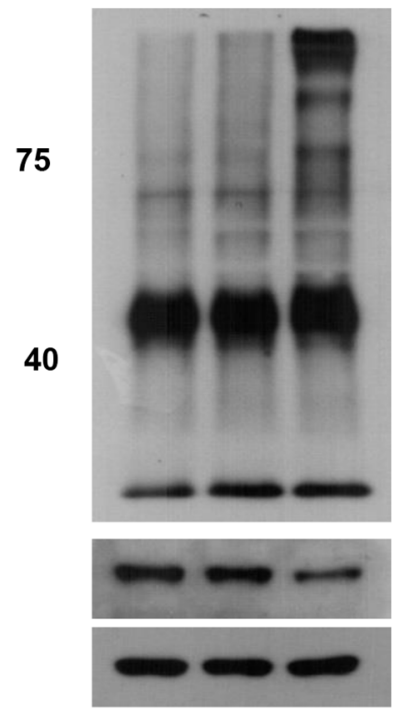

IP: Mcl-1

WB: Ub

Mcl-1

$\beta$-actin

Figure 4: Role of Mcl-1 in the sensitizing function of metformin. DLD-1 cells were treated with indicated metformin doses $(0,2.5,5$, and $10 \mathrm{mM})$ for $20 \mathrm{~h}$. The mRNA expression levels of Mcl-1 and actin were determined by real time -PCR (A) and reverse transcriptase -PCR (B). (C) DLD-1 cells were treated with or without metformin in the presence of cyclohexamide $(\mathrm{CHX})(10 \mu \mathrm{g} / \mathrm{ml})$ for the indicated time periods. The Mcl-1 and actin protein levels were determined by western blotting. Actin expression was used as a loading control. The band intensity of the Mcl-1 protein was measured using the public domain JAVA image-processing program ImageJ. (D) Metformin-treated cells were treated with or without MG132 and subjected to western blot analysis using anti-Mcl-1 and anti-actin antibodies. (E) Metformin-treated cells were subjected to immunoprecipitation with anti-Ub antibody and immunoblotted for Mcl-1. Error bars represent standard error of the mean (SEM) from three separate experiments. Asterisk * represents a statistically significant difference between metformin-treated cells and untreated control cells at $p<0.05$. 
numerous human tumors [56-59]. To our knowledge, this is the first time that metformin has been shown to decrease Mcl-1 expression in CRC cells. Even though Mcl-1 potentially could be controlled at multiple levels [60, 61], metformin did not affect the transcriptional level, protein stability, or degradation of Mcl-1 in CRC cells, indicating that the metformin-induced decrease of $\mathrm{Mcl}-1$ protein was not because of transcriptional or post-translational regulation.

We hypothesized that metformin inhibits de novo protein synthesis and we studied mechanisms that increase the stability of Mcl-1 in CRC cells. Notably, we found that stable binding of Mcl-1 with the E3 ligase, Mule, may be one of the prominent mechanisms that increase the stability of Mcl-1 in CRC cells. We believe that this is the first report of a transient association between Mule and Mcl-1 in CRC cells. Mule is a novel ubiquitin, which can specifically interact with Mcl-1 [43, 62]. We detected a stable prolonged association between Mcl-1 and Mule in metformin-treated DLD-1 cells, in which Mcl-1 undergoes prominent ubiquitination and degradation. We found an induced ubiquitination of Mcl-1 as well as a stable association of Mcl-1 with its specific E3 ligase, Mule, in CRC cells treated with metformin. Metformin induced down-regulation of $\mathrm{Mcl}-1$ protein expression at the post-translational level (Figure 3B). Furthermore, Mule has been determined to regulate the degradation of Mcl-1 proteins. Mule has been known to be a multiadaptor protein and an E3 ligase. Gomes-Bouqie et al. reported that Mule is responsible for degrading Mcl-1 by proteasomes in prostate cancer cells [63]. In this study, metformin attenuated cell death when Mule was downregulated by Mule siRNA (Figure 5C). These data show that metformin increased the stability of Mule in
A

A

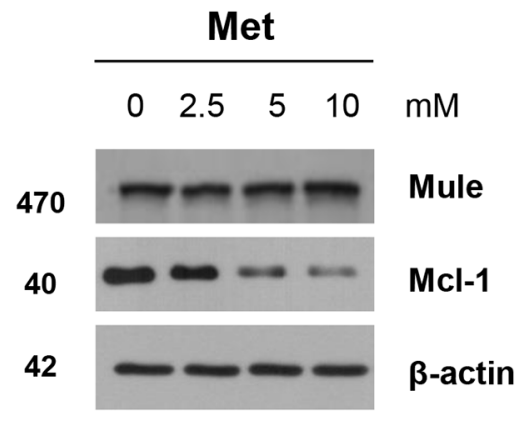

C

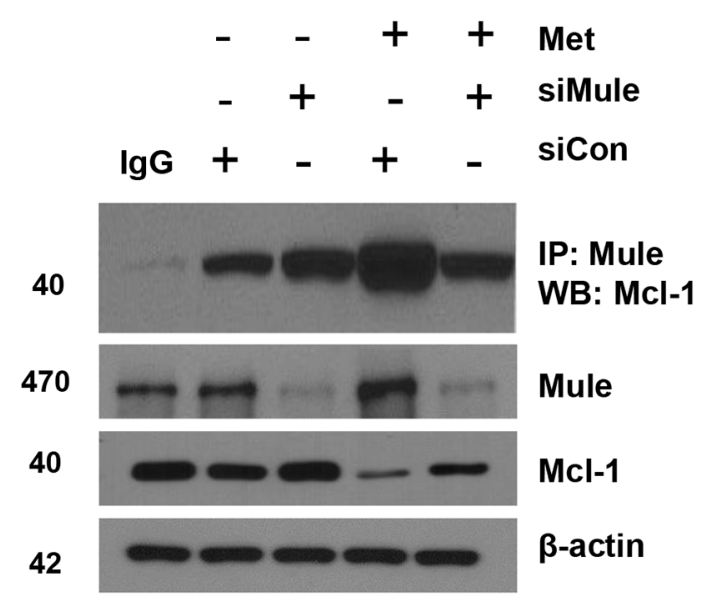

B IgG Con Met
40

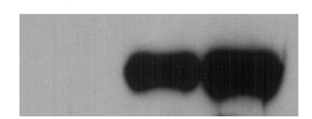

470

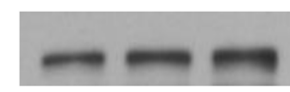

40

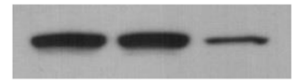

42

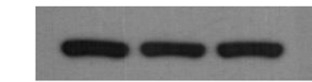

IP: Mule

WB: Mcl-1

Mule

Mcl-1

$\beta$-actin

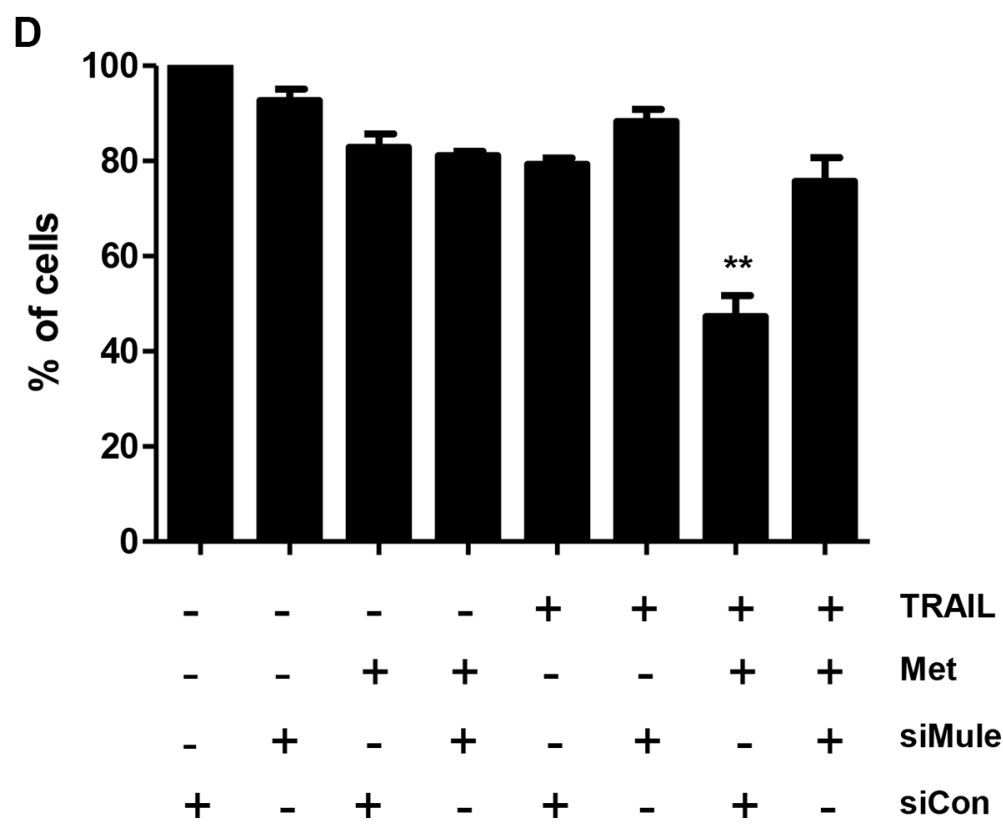

Figure 5: Metformin enhanced Mule/Mcl-1 complex detected in human CRC cells. (A) DLD-1 cells were treated with indicated metformin doses $(0,2.5,5$, and $10 \mathrm{mM})$ for $20 \mathrm{~h}$ and $50 \mu \mathrm{g}$ of protein lysates were immunoblotted using anti-Mule and antiMcl-1 antibodies. (B) DLD-1 cells were treated with metformin for $20 \mathrm{~h}$ and immunoprecipitated with anti-Mule antibody or with IgG (16 h) and immunoblotted for Mcl-1. (C) Small-inhibitory RNA (siRNA)-mediated inhibition of Mule in DLD-1 cells. Cells were treated with metformin for $20 \mathrm{~h}$ and immunoprecipitated with anti-Mule antibody or with $\operatorname{IgG}(16 \mathrm{~h})$ and immunoblotted for Mcl-1. Western blot analysis showing Mule, Mcl-1 and actin. (D) Measurement of apoptotic index in control siRNA and Mule siRNA treated DLD-1 cells by trypan blue assay after metformin and TRAIL treatment. ${ }^{* *} P<0.01$. 
A
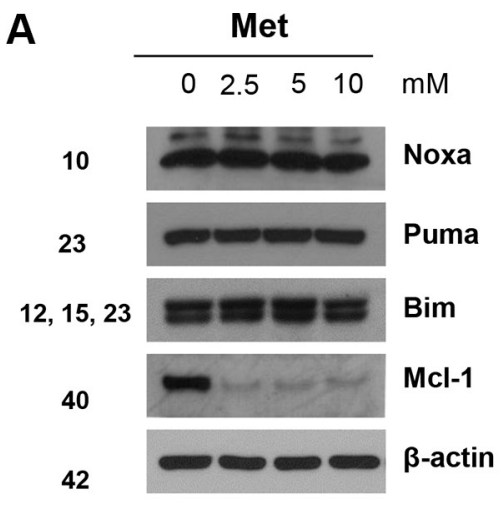

C

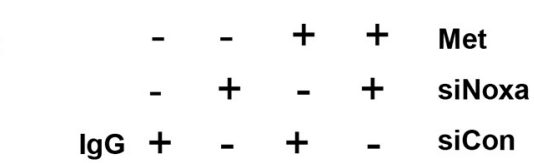

40

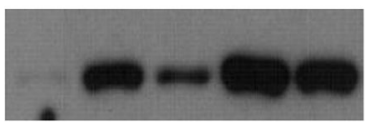

\section{IP: Mule}

WB: Mcl-1

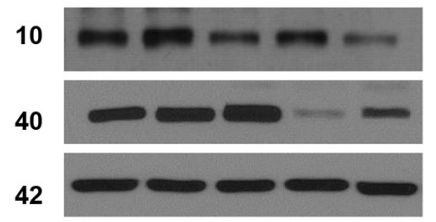

Noxa

Mcl-1

$\beta$-actin

B IgG Con Met

40

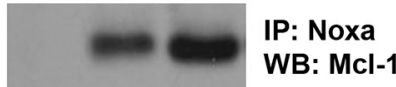

10

40

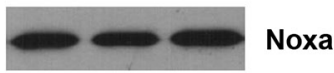

42
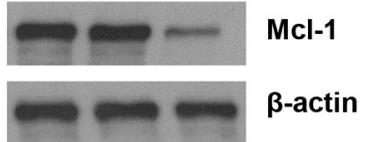

D

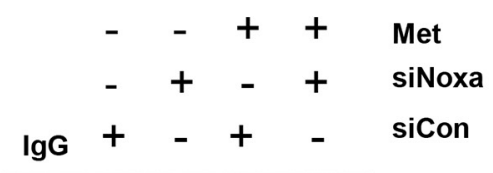

75

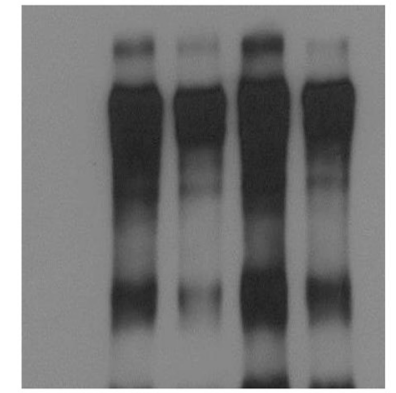

IP: $\mathrm{Mcl}-1$

WB: Ub

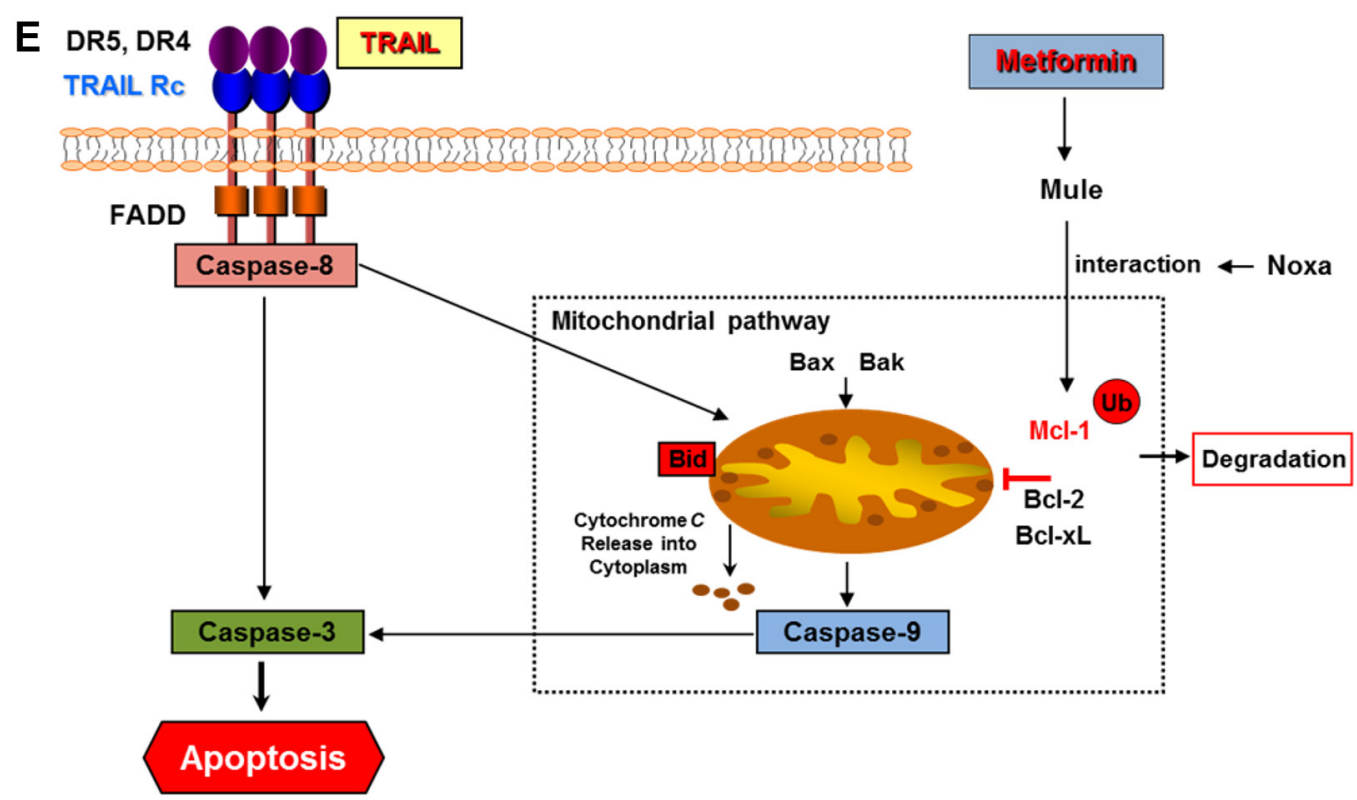

Figure 6: Mule is required for Noxa-induced Mcl-1 degradation following metformin treatment. (A) DLD-1 cells were treated with indicated metformin doses $(0,2.5,5$, and $10 \mathrm{mM})$ for $20 \mathrm{~h}$ and $50 \mu \mathrm{g}$ of protein lysates were immunoblotted using anti-Noxa, anti-Puma, anti-Bim, and anti-Mcl-1 antibodies. (B) DLD-1 cells were treated with metformin for $20 \mathrm{~h}$ and immunoprecipitated with anti-Noxa antibody or with IgG (16 h) and immunoblotted for Mcl-1. (C and D) Small-inhibitory RNA (siRNA)-mediated inhibition of Mule in DLD-1 cells. Cells were treated with metformin for $20 \mathrm{~h}$ and immunoprecipitated with anti-Mule antibody or with IgG (16 h) and immunoblotted for Mcl-1. Western blot analysis showing Mule, Mcl-1 and actin. DLD-1 cells were transfected with a control or Noxa siRNA, and after $40 \mathrm{~h}$ the cells were treated with $10 \mathrm{mM}$ metformin for $16 \mathrm{~h}$, and the cell extracts were subjected to immunoprecipitation with an anti-Mcl-1 antibody followed by immunoblot analysis for the indicated proteins. (E) Schematic diagram for working model of metformin sensitizing TRAIL-induced apoptosis. 
CRC cells. We also found that metformin counteracts Mcl-1 by inhibiting Mcl-1 for ubiquitin proteasomeinduced degradation in the CRC cells. Noxa also appears to play a major regulator of Mcl-1 stability. Noxa has been presented to negatively regulate Mcl-1 [64], potentially by increasing the binding of Mule (E3 ligase) and decreasing the binding of the USP9X (deubiquitinase) to Mcl-1 [63]. This is confirmed by our results that Mcl-1 interacts with Noxa in control cells and that the knockdown of Noxa by silencing RNA elevated Mcl-1 protein (Figure 6C). In addition, metformin quickly replaces Noxa from Mcl-1, allowing Mule binding and degradation by the ubiquitinproteasome pathway to occur (Figure 6D). In accordance with a previous report, our data show that Noxa protein was not altered by metformin [65].

In vitro, the Mcl-1 protein was decreased by either metformin or TRAIL, and combination of the two drugs further decreased Mcl-1 protein levels. As Mcl-1 is strongly increased by proteasome degradation, we studied the effects of metformin and TRAIL with and without of MG132, a proteasome inhibitor. Our results showed that metformin and TRAIL did not change Mcl-1 with MG132, indicating that metformin and TRAIL induced proteasome degradation of Mcl-1. These findings imply that metformin and TRAIL regulate $\mathrm{Mcl}-1$ protein partially through proteasome degradation.

Additionally, AMPK has been reported to be a major regulator of metformin in various cancer types. In the present study, although it is possible that AMPK could be activated by metformin, which would be inconsistent with previous studies, the anti-proliferation effect of metformin does not require AMPK activation. When AMPK $\alpha$ was knocked down by silencing RNA, the survival rates of the cells treated with metformin, TRAIL, or the combination were not statistically significantly different (data not shown). In addition, the decrease of Mcl-1 by metformin was observed even in the absence of AMPK $\alpha$, showing that downregulation of Mcl-1 by metformin is independent of AMPK activation.

STAT3 is a main modulator in inflammationmediated tumorigenesis, including $\mathrm{CRC}$, by promoting tumor cell proliferation and survival. We found that metformin significantly suppressed the phosphorylation of STAT3 in CRC cells. This observation is consistent with the previous findings that metformin inhibited the transcriptional activation of STAT3 in various cancer cell lines [66-68]. STAT3 is also known to modulate Mcl-1 translation, which supports STAT3-dependent cell growth and proliferation. In our study, however, decreasing STAT3 levels produced no change in the cells' sensitivity cell to metformin. Moreover, Mcl-1 protein did not change in STAT3-silenced cells. In our study, we also detected a down-regulation of STAT3 in metformin-treated cells (data not shown). Our previous studies have reported that inhibition of STAT3 by S31-201 (STAT3 inhibitor) or silencing RNA led to a significant decrease in the level of Mcl-1 and enhanced HSP90 inhibitor (NVP-AUY922)- induced apoptosis in CRC cells [54]. Therefore, inhibition of STAT3 may be an effective medical treatment to sensitize cancer cell to apoptotic stimuli such as radiation or anticancer drugs. Furthermore, a JAK/STAT3-signaled decrease of Mcl-1 protein is considered to be a crucial factor responsible for metformin-induced sensitization to TRAIL in CRC cells. Thus, we propose that metformin may cause a decrease of Mcl-1 through the JAK/STAT3 signal of its regulation. Here, we determined that metformin inhibited the phosphorylation of JAK2 and STAT3, but could not effectively decrease the Mcl-1 level (Supplementary Figure S1). However, this downregulation of STAT3 had no effect on Mcl-1 expression or TRAIL sensitization in metformin-treated cells (data not shown). Hence, these data show that the decrease of Mcl-1 by metformin is independent of the down-regulation of JAK/STAT3 expression in CRC cells.

Last, it has been found in breast cancer cells that ERK1/2 can phosphorylate and stabilize Mcl-1 [69]. We found ERK1/2 and its active form pERK1/2 to be upregulated in all the CRC cells examined; their levels were downregulated after metformin treatment, pointing to increased stability of these proteins (Supplementary Figure S1). Inactivating pERK1/2 with the MEK inhibitor, U0126, promoted decline of Mcl-1 levels in CRC cells (data not shown).

In conclusion, our findings show that the novel mechanism of cell death induced by metformin involves TRAIL sensitization and degradation of Mcl-1, important for an understanding of its role in the pathophysiology, diagnosis, and ways to treat cancer. Finally, these data are the first to indicate that metformin suppresses cell proliferation and enhances apoptosis when used in combination with TRAIL in human CRC cells, possibly through Noxa-mediated increase in Mcl-1 degradation via the ubiquitin-proteasome pathway.

\section{MATERIALS AND METHODS}

\section{Cell culture}

The human colon carcinoma cell lines DLD-1, HT29, Colo205 and HCT116 were obtained from the American Type Culture Collection (ATCC, Manassas, VA, USA) and maintained according to the ATCC's instructions. Primary cultures of human normal colon cells (FHC) and their corresponding growth medium (DMEM:F12) were purchased from ATCC (Manassas, VA, USA). All cell lines were grown in RPMI 1640 supplemented with $10 \% \mathrm{FBS}$ and l-glutamine and grown in a $37^{\circ} \mathrm{C}$ humidified chamber $5 \% \mathrm{CO}_{2}$.

\section{Reagents and antibodies}

Metformin was purchased from Wako (Richmond, VA, USA). TRAIL (Recombinant human) was purchased from Millipore (Millipore, Darmstadt, Germany.) Protein 
G PLUS-Agarose, Anti-Bax, anti-Bcl-2, anti-Mcl-1(IP), anti-Ub and anti-Bcl-xL were purchased from Santa Cruz Biotechnology (Santa Cruz, CA, USA). Anti-XIAP, anti-phospho ERK, anti-ERK, anti-phospho JAK2, antiJAK2, anti-phospho AMPK, anti-AMPK, anti-phospho mTOR, anti-mTOR, anti-phospho AKT, anti-AKT, antiphsopho GSK3 $\beta$, anti-GSK3 $\beta$, anti-Noxa, anti-Puma, antiBim, anti-phospho Mcl-1, anti-Mcl-1(WB), anti-cleaved caspase-3, anti-cleaved caspase-8, anti-cleaved caspase-9, anti-phospho STAT3, anti-STAT3, and anti-PARP-1 were purchased from Cell Signaling (Beverly, MA, USA). Anti-actin antibody was purchased from Sigma (Sigma, St. Louis, MO). Anti-Mule antibody was purchased from Abcam (Cat. No. ab70161). For the secondary antibodies, anti-mouse-IgG-HRP and anti-rabbit-IgG-HRP were purchased from Cell Signaling (Beverly, MA, USA).

\section{Small interfering RNA (siRNA)}

Mcl-1 siRNA (Cat. No. SC-35877), Noxa siRNA (Cat. No. SC-37305), Mule siRNA (Cat. No. SC-61758) and negative control siRNA (Cat. No. SC-37007) were obtained from SantaCruz Biotechnology (Santa Cruz, CA, USA). Cells were transfected with siRNA oligonucleotides using Lipofectamine RNAi Max reagents (Invitrogen) according to the manufacturer's introductions. After $24 \mathrm{~h}$ of transfection, cells were treated with TRAIL and metformin for further analysis.

\section{Transient and stable transfection}

Cells were transfected with human Mcl-1 tagged with Flag in pCDNA3.1 vector or the corresponding empty vector (pCDNA). Mcl-1 overexpression plasmid pTOPO-Mcl-1 (Plasmid No 21605) was purchased from Addgene. Cells were selected with $1 \mathrm{mg} / \mathrm{ml} \mathrm{G} 418$ for 2 weeks and five clones were pooled and then maintained in $500 \mu \mathrm{g} / \mathrm{ml} \mathrm{G} 418$.

\section{Survival assay}

Cells were grown in tissue culture-coated 96-well plates and treated as described in Results. Cells were then treated with 3-(4,5-dimethylthiazol-2-yl)-2,5diphenyltetrazolium bromide (MTT) assay (Roche Molecular Biochemical, Indianapolis, IN, USA) for $3 \mathrm{~h}$ at $37^{\circ} \mathrm{C}$ in an atmosphere of $5 \% \mathrm{CO} 2$. Absorbance at $450 \mathrm{~nm}$ was determined using an enzyme-linked immunosorbent assay plate reader. The total number of cells in each well was counted under a microscope. Then, cells were dissociated and stained with trypan blue (Amresco, Inc., Solon, OH, USA).

\section{Colony formation assay}

Colony formation on plate was conducted in 6-well cell culture plates as previously described [70].

\section{Apoptosis assay (flow cytometry)}

The translocation of phosphatidylserine, one of the markers of apoptosis, from the inner to the outer leaflet of plasma membrane was detected by binding of allophycocyanin (APC)-conjugated annexin V. Briefly, DLD-1 cells untreated or treated with metformin, TRAIL, or a combination of the two agents was resuspended for $24 \mathrm{~h}$ in the binding buffer provided in the Annexin V-FITC Apoptosis Detection Kit (BioBud, Cat. LS-02-100). Cells were mixed with $1.25 \mu \mathrm{L}$ Annexin V-FITC reagent and incubated for $30 \mathrm{~min}$ at room temperature in the dark. The staining was terminated and cells were immediately analyzed by flow cytometry.

\section{Western blotting}

Western blotting was carried out as previously described [54]. Immunoreactive proteins were visualized by the chemiluminescence protocol (ECL, Dogen, Seoul, Korea).

\section{RT-PCR analysis}

Total RNA extraction was performed using the TRIzol reagent (Life Technologies, Rockville, MD, USA), according to the manufacturer's instructions. Amplification of transcripts was performed by reverse transcriptase polymerase chain reaction kit (Life Technologies). PCR amplification was performed using the following primers: Mcl-1, forward: 5'- GCG ACT GGC AAA GCT TGG CCT CAA-3', reverse: 5'- GTT ACA GCT TGG ATC CCA ACT GCA $-3^{\prime}$.

\section{Real time PCR}

Total RNA was extracted by using TRIzol reagent (Life Technologies). Amplification of transcripts was performed by reverse transcriptase polymerase chain reaction kit (Life Technologies). RT-PCR was performed on an Applied Biosystems 9700 RT-PCR using genespecific oligonucleotide primer for Taqman probes (Applied Biosystems). Taqman probes were as follows: GAPDH (Hs99999905_m1), Mcl-1 (HS01050896_m1). For expression of mRNA $\bar{A}$, gene expression was normalized by the GAPDH.

\section{Co-immunoprecipitation}

Cells were washed with ice-cold PBS and incubated on ice for 5 min with $300 \mu l$ lysis buffer (Cell Signaling, Cat. No. 9803) (1 mM PMSF, protease inhibitor, and phosphatase inhibitor). The cells were scrape-harvested, and cellular debris were removed by centrifugation for $5 \mathrm{~min}$ at $15,000 \mathrm{rpm}$ at $4^{\circ} \mathrm{C}$, and the concentration of protein was determined by BCA assay (Thermo Scientific). Cell supernatants were incubated with primary 
antibody for overnight at $4^{\circ} \mathrm{C}$, followed by addition of $50 \mu \mathrm{l}$ protein $\mathrm{G}$ agarose beads (50\% slurry) for $1 \mathrm{~h}$ at $4^{\circ} \mathrm{C}$. Immunoprecipitates were washed five times with icecold lysis buffer, separated by centrifugation for $30 \mathrm{~s}$ at $10,000 \mathrm{rpm}$, and then heated with $2 \mathrm{x}$ sample buffer for electrophoresis and Western blot analysis.

\section{Statistical analysis}

Statistical analysis was carried out using Graphpad InStat 6 software (GraphPad Software, Inc., San Diego, CA, USA). The results were expressed as the mean of arbitrary values \pm SEM. All results were evaluated using an unpaired Student's $t$ test, where a $p$-value of less than 0.05 was considered significant.

\section{Abbreviations}

DR5; death receptor-5; PARP: poly (ADP-ribose) polymerase; PBS: phosphate-buffered saline solution; PI: propidium iodide; SDS-PAGE: sodium dodecyl sulfate polyacrylamide gel electrophoresis; TNF: tumor necrosis factor; TRAIL: tumor necrosis factor-related apoptosisinducing ligand.

\section{ACKNOWLEDGMENTS AND FUNDING}

This research was supported by the Brain Korea (BK) 21 Plus Program and the grant of the Korea Health Technology R\&D Project through the Korea Health Industry Development Institute (KHIDI), funded by the Ministry of Health \& Welfare, Republic of Korea (grant number: HI15C1665).

\section{CONFLICTS OF INTEREST}

None.

\section{REFERENCES}

1. Chua TC, Esquivel J, Pelz JO, Morris DL. Summary of current therapeutic options for peritoneal metastases from colorectal cancer. J Surg Oncol. 2013; 107:566-573.

2. Saltz LB, Cox JV, Blanke C, Rosen LS, Fehrenbacher L, Moore MJ, Maroun JA, Ackland SP, Locker PK, Pirotta N, Elfring GL, Miller LL. Irinotecan plus fluorouracil and leucovorin for metastatic colorectal cancer. Irinotecan Study Group. The New England journal of medicine. 2000; 343:905-914.

3. Kabbinavar FF, Hambleton J, Mass RD, Hurwitz HI, Bergsland E, Sarkar S. Combined analysis of efficacy: the addition of bevacizumab to fluorouracil/leucovorin improves survival for patients with metastatic colorectal cancer. Journal of clinical oncology. 2005; 23:3706-3712.

4. Cassidy J, Clarke S, Diaz-Rubio E, Scheithauer W, Figer A, Wong R, Koski S, Lichinitser M, Yang TS, Rivera F,
Couture F, Sirzen F, Saltz L. Randomized phase III study of capecitabine plus oxaliplatin compared with fluorouracil/ folinic acid plus oxaliplatin as first-line therapy for metastatic colorectal cancer. Journal of clinical oncology. 2008; 26:2006-2012.

5. Saltz LB, Clarke S, Diaz-Rubio E, Scheithauer W, Figer A, Wong R, Koski S, Lichinitser M, Yang TS, Rivera F, Couture F, Sirzen F, Cassidy J. Bevacizumab in combination with oxaliplatin-based chemotherapy as first-line therapy in metastatic colorectal cancer: a randomized phase III study. Journal of clinical oncology. 2008; 26:2013-2019.

6. Pan G, O'Rourke K, Chinnaiyan AM, Gentz R, Ebner R, Ni J, Dixit VM. The receptor for the cytotoxic ligand TRAIL. Science. 1997; 276:111-113.

7. Schneider P, Thome M, Burns K, Bodmer JL, Hofmann K, Kataoka T, Holler N, Tschopp J. TRAIL receptors 1 (DR4) and 2 (DR5) signal FADD-dependent apoptosis and activate NF-kappaB. Immunity. 1997; 7:831-836.

8. Wu GS, Burns TF, McDonald ER 3rd, Jiang W, Meng R, Krantz ID, Kao G, Gan DD, Zhou JY, Muschel R, Hamilton SR, Spinner NB, Markowitz S, et al. KILLER/ DR5 is a DNA damage-inducible p53-regulated death receptor gene. Nature genetics. 1997; 17:141-143.

9. Walczak H, Degli-Esposti MA, Johnson RS, Smolak PJ, Waugh JY, Boiani N, Timour MS, Gerhart MJ, Schooley KA, Smith CA, Goodwin RG, Rauch CT. TRAIL-R2: a novel apoptosis-mediating receptor for TRAIL. The European Molecular Biology Organization journal. 1997; 16:5386-5397.

10. Wiley SR, Schooley K, Smolak PJ, Din WS, Huang CP, Nicholl JK, Sutherland GR, Smith TD, Rauch C, Smith CA, et al. Identification and characterization of a new member of the TNF family that induces apoptosis. Immunity. 1995; 3:673-682.

11. Lacour S, Hammann A, Wotawa A, Corcos L, Solary E, Dimanche-Boitrel MT. Anticancer agents sensitize tumor cells to tumor necrosis factor-related apoptosis-inducing ligand-mediated caspase- 8 activation and apoptosis. Cancer research. 2001; 61:1645-1651.

12. Gibson SB, Oyer R, Spalding AC, Anderson SM, Johnson GL. Increased expression of death receptors 4 and 5 synergizes the apoptosis response to combined treatment with etoposide and TRAIL. Molecular and cellular biology. 2000; 20:205-212.

13. Singh TR, Shankar S, Chen X, Asim M, Srivastava RK. Synergistic interactions of chemotherapeutic drugs and tumor necrosis factor-related apoptosis-inducing ligand/ Apo-2 ligand on apoptosis and on regression of breast carcinoma in vivo. Cancer research. 2003; 63:5390-5400.

14. Zhang L, Fang B. Mechanisms of resistance to TRAILinduced apoptosis in cancer. Cancer gene therapy. 2005; 12:228-237.

15. Lee DH, Rhee JG, Lee YJ. Reactive oxygen species upregulate p53 and Puma; a possible mechanism for apoptosis during combined treatment with TRAIL and wogonin. British journal of pharmacology. 2009; 157:1189-1202. 
16. Kim JY, Kim EH, Kim SU, Kwon TK, Choi KS. Capsaicin sensitizes malignant glioma cells to TRAILmediated apoptosis via DR5 upregulation and survivin downregulation. Carcinogenesis. 2010; 31:367-375.

17. Moon DO, Asami Y, Long H, Jang JH, Bae EY, Kim BY, Choi YH, Kang CH, Ahn JS, Kim GY. Verrucarin A sensitizes TRAIL-induced apoptosis via the upregulation of DR5 in an eIF2alpha/CHOP-dependent manner. Toxicology in vitro. 2013; 27:257-263.

18. Kim J, Kim SY, Kang S, Yoon HR, Sun BK, Kang D, Kim JH, Song JJ. HSP27 modulates survival signaling networks in cells treated with curcumin and TRAIL. Cellular signalling. 2012; 24:1444-1452.

19. Siddiqui IA, Malik A, Adhami VM, Asim M, Hafeez BB, Sarfaraz S, Mukhtar H. Green tea polyphenol EGCG sensitizes human prostate carcinoma LNCaP cells to TRAIL-mediated apoptosis and synergistically inhibits biomarkers associated with angiogenesis and metastasis. Oncogene. 2008; 27:2055-2063.

20. Fulda S, Debatin KM. Sensitization for tumor necrosis factor-related apoptosis-inducing ligand-induced apoptosis by the chemopreventive agent resveratrol. Cancer research. 2004; 64:337-346.

21. Pei Z, Chu L, Zou W, Zhang Z, Qiu S, Qi R, Gu J, Qian C, Liu X. An oncolytic adenoviral vector of Smac increases antitumor activity of TRAIL against HCC in human cells and in mice. Hepatology. 2004; 39:1371-1381.

22. Shin EA, Sohn EJ, Won G, Choi JU, Jeong M, Kim B, Kim MJ, Kim SH. Upregulation of microRNA135a-3p and death receptor 5 plays a critical role in Tanshinone I sensitized prostate cancer cells to TRAIL induced apoptosis. Oncotarget. 2014; 5:5624-5636. doi: 10.18632/ oncotarget. 2152 .

23. Griffith TS, Chin WA, Jackson GC, Lynch DH, Kubin MZ. Intracellular regulation of TRAIL-induced apoptosis in human melanoma cells. Journal of immunology. 1998; 161:2833-2840.

24. Nesterov A, Lu X, Johnson M, Miller GJ, Ivashchenko Y, Kraft AS. Elevated AKT activity protects the prostate cancer cell line LNCaP from TRAIL-induced apoptosis. The Journal of biological chemistry. 2001; 276:10767-10774.

25. Sanlioglu AD, Dirice E, Aydin C, Erin N, Koksoy S, Sanlioglu S. Surface TRAIL decoy receptor-4 expression is correlated with TRAIL resistance in MCF7 breast cancer cells. BMC cancer. 2005; 5:54.

26. Zhang Y, Zhang B. TRAIL resistance of breast cancer cells is associated with constitutive endocytosis of death receptors 4 and 5. Molecular cancer research. 2008; 6:1861-1871.

27. Del Barco S, Vazquez-Martin A, Cufi S, Oliveras-Ferraros C, Bosch-Barrera J, Joven J, Martin-Castillo B, Menendez JA. Metformin: multi-faceted protection against cancer. Oncotarget. 2011; 2:896-917. doi: 10.18632/oncotarget.2152.

28. Menendez JA, Quirantes-Pine R, Rodriguez-Gallego E, Cufi S, Corominas-Faja B, Cuyas E, Bosch-Barrera J, Martin-
Castillo B, Segura-Carretero A, Joven J. Oncobiguanides: Paracelsus' law and nonconventional routes for administering diabetobiguanides for cancer treatment. Oncotarget. 2014; 5:2344-2348. doi: 10.18632/oncotarget.1965.

29. Zhang P, Li H, Tan X, Chen L, Wang S. Association of metformin use with cancer incidence and mortality: a metaanalysis. Cancer epidemiology. 2013; 37:207-218.

30. Currie CJ, Poole CD, Jenkins-Jones S, Gale EA, Johnson JA, Morgan CL. Mortality after incident cancer in people with and without type 2 diabetes: impact of metformin on survival. Diabetes care. 2012; 35:299-304.

31. Zhou G, Myers R, Li Y, Chen Y, Shen X, Fenyk-Melody J, Wu M, Ventre J, Doebber T, Fujii N, Musi N, Hirshman MF, Goodyear LJ, et al. Role of AMP-activated protein kinase in mechanism of metformin action. The Journal of clinical investigation. 2001; 108:1167-1174.

32. Zoncu R, Efeyan A, Sabatini DM. mTOR: from growth signal integration to cancer, diabetes and ageing. Nature reviews Molecular cell biology. 2011; 12:21-35.

33. Lin YC, Wu MH, Wei TT, Lin YC, Huang WC, Huang LY, Lin YT, Chen CC. Metformin sensitizes anticancer effect of dasatinib in head and neck squamous cell carcinoma cells through AMPK-dependent ER stress. Oncotarget. 2014; 5:298-308. doi: 10.18632/oncotarget.1628.

34. Yue W, Zheng X, Lin Y, Yang CS, Xu Q, Carpizo D, Huang H, DiPaola RS, Tan XL. Metformin combined with aspirin significantly inhibit pancreatic cancer cell growth in vitro and in vivo by suppressing anti-apoptotic proteins Mcl-1 and Bcl-2. Oncotarget. 2015; 6:21208-21224. doi: 10.18632/oncotarget.4126.

35. Braghiroli MI, de Celis Ferrari AC, Pfiffer TE, Alex AK, Nebuloni D, Carneiro AS, Caparelli F, Senna L, Lobo J, Hoff PM, Riechelmann RP. Phase II trial of metformin and paclitaxel for patients with gemcitabine-refractory advanced adenocarcinoma of the pancreas. Ecancermedicalscience. 2015; 9:563.

36. Bao B, Wang Z, Ali S, Ahmad A, Azmi AS, Sarkar SH, Banerjee S, Kong D, Li Y, Thakur S, Sarkar FH. Metformin inhibits cell proliferation, migration and invasion by attenuating CSC function mediated by deregulating miRNAs in pancreatic cancer cells. Cancer prevention research. 2012; 5:355-364.

37. Kisfalvi K, Eibl G, Sinnett-Smith J, Rozengurt E. Metformin disrupts crosstalk between $\mathrm{G}$ protein-coupled receptor and insulin receptor signaling systems and inhibits pancreatic cancer growth. Cancer research. 2009; 69:6539-6545.

38. Mei ZB, Zhang ZJ, Liu CY, Liu Y, Cui A, Liang ZL, Wang GH, Cui L. Survival benefits of metformin for colorectal cancer patients with diabetes: a systematic review and meta-analysis. Public Library of Science. 2014; 9:e91818.

39. Kwan HT, Chan DW, Cai PC, Mak CS, Yung MM, Leung TH, Wong OG, Cheung AN, Ngan HY. AMPK activators suppress cervical cancer cell growth through inhibition of DVL3 mediated Wnt/beta-catenin signaling activity. Public Library of Science. 2013; 8:e53597. 
40. Kim NY, Lee HY, Lee C. Metformin targets Axl and Tyro3 receptor tyrosine kinases to inhibit cell proliferation and overcome chemoresistance in ovarian cancer cells. International journal of oncology. 2015; 47:353-360.

41. Scotland S, Saland E, Skuli N, de Toni F, Boutzen H, Micklow E, Senegas I, Peyraud R, Peyriga L, Theodoro F, Dumon E, Martineau Y, Danet-Desnoyers G, et al. Mitochondrial energetic and AKT status mediate metabolic effects and apoptosis of metformin in human leukemic cells. Leukemia. 2013; 27:2129-2138.

42. Nangia-Makker P, Yu Y, Vasudevan A, Farhana L, Rajendra SG, Levi E, Majumdar AP. Metformin: a potential therapeutic agent for recurrent colon cancer. Public Library of Science. 2014; 9:e84369.

43. Zhong Q, Gao W, Du F, Wang X. Mule/ARF-BP1, a BH3only E3 ubiquitin ligase, catalyzes the polyubiquitination of Mcl-1 and regulates apoptosis. Cell. 2005; 121:1085-1095.

44. Lee WS, Park YL, Kim N, Oh HH, Son DJ, Kim MY, Oak CY, Chung CY, Park HC, Kim JS, Myung DS, Cho SB, Kim HS, et al. Myeloid cell leukemia-1 is associated with tumor progression by inhibiting apoptosis and enhancing angiogenesis in colorectal cancer. American journal of cancer research. 2015; 5:101-113.

45. Rieber M, Medina JD, Strasberg-Rieber M. Relationship of Mcl-1 isoforms, ratio p21WAF1/cyclin A, and Jun kinase phosphorylation to apoptosis in human breast carcinomas. Biochemical and biophysical research communications. 2002; 297:943-949.

46. Koehler BC, Jassowicz A, Scherr AL, Lorenz S, Radhakrishnan P, Kautz N, Elssner C, Weiss J, Jaeger D, Schneider M, Schulze-Bergkamen H. Pan-Bcl-2 inhibitor Obatoclax is a potent late stage autophagy inhibitor in colorectal cancer cells independent of canonical autophagy signaling. BMC cancer. 2015; 15:919.

47. Jonchere B, Vetillard A, Toutain B, Lam D, Bernard AC, Henry C, De Carne Trecesson S, Gamelin E, Juin P, Guette C, Coqueret $\mathrm{O}$. Irinotecan treatment and senescence failure promote the emergence of more transformed and invasive cells that depend on anti-apoptotic Mcl-1. Oncotarget. 2015; 6:409-426. doi: 10.18632/oncotarget.2774.

48. Thomas LW, Lam C, Edwards SW. Mcl-1; the molecular regulation of protein function. Federation of European Biochemical Societies letters. 2010; 584:2981-2989.

49. Ding Q, He X, Hsu JM, Xia W, Chen CT, Li LY, Lee DF, Liu JC, Zhong Q, Wang X, Hung MC. Degradation of Mcl-1 by beta-TrCP mediates glycogen synthase kinase 3-induced tumor suppression and chemosensitization. Molecular and cellular biology. 2007; 27:4006-4017.

50. Maurer U, Charvet C, Wagman AS, Dejardin E, Green DR. Glycogen synthase kinase-3 regulates mitochondrial outer membrane permeabilization and apoptosis by destabilization of MCL-1. Molecular cell. 2006; 21:749-760.

51. Wertz IE, Kusam S, Lam C, Okamoto T, Sandoval W, Anderson DJ, Helgason E, Ernst JA, Eby M, Liu J, Belmont LD, Kaminker JS, O’Rourke KM, et al. Sensitivity to antitubulin chemotherapeutics is regulated by MCL1 and FBW7. Nature. 2011; 471:110-114.

52. Inuzuka H, Shaik S, Onoyama I, Gao D, Tseng A, Maser RS, Zhai B, Wan L, Gutierrez A, Lau AW, Xiao Y, Christie AL, Aster J, et al. $\mathrm{SCF}(\mathrm{FBW7})$ regulates cellular apoptosis by targeting MCL1 for ubiquitylation and destruction. Nature. 2011; 471:104-109.

53. Mojsa B, Lassot I, Desagher S. Mcl-1 ubiquitination: unique regulation of an essential survival protein. Cells. 2014; 3:418-437.

54. Lee DH, Sung KS, Bartlett DL, Kwon YT, Lee YJ. HSP90 inhibitor NVP-AUY922 enhances TRAIL-induced apoptosis by suppressing the JAK2-STAT3-Mcl-1 signal transduction pathway in colorectal cancer cells. Cellular signalling. 2015; 27:293-305.

55. Zhang T, Qu S, Shi Q, He D, Jin X. Evodiamine induces apoptosis and enhances TRAIL-induced apoptosis in human bladder cancer cells through mTOR/S6K1-mediated downregulation of Mcl-1. International journal of molecular sciences. 2014; 15:3154-3171.

56. Zhang T, Zhao C, Luo L, Zhao H, Cheng J, Xu F. The expression of Mcl-1 in human cervical cancer and its clinical significance. Medical oncology. 2012; 29:1985-1991.

57. Likui W, Qun L, Wanqing Z, Haifeng S, Fangqiu L, Xiaojun L. Prognostic role of myeloid cell leukemia-1 protein (Mcl-1) expression in human gastric cancer. Journal of Surgery Oncology. 2009; 100:396-400.

58. Luo L, Zhang T, Liu H, Lv T, Yuan D, Yao Y, Lv Y, Song Y. MiR-101 and Mcl-1 in non-small-cell lung cancer: expression profile and clinical significance. Medical oncology. 2012; 29:1681-1686.

59. Henderson-Jackson EB, Helm J, Ghayouri M, Hakam A, Nasir A, Leon M, Bui M, Yeatman T, Coppola D. Correlation between Mcl-1 and pAKT protein expression in colorectal cancer. International journal of clinical and experimental pathology. 2010; 3:768-774.

60. Opferman JT. Unraveling MCL-1 degradation. Cell death and differentiation. 2006; 13:1260-1262.

61. Mills JR, Hippo Y, Robert F, Chen SM, Malina A, Lin CJ, Trojahn U, Wendel HG, Charest A, Bronson RT, Kogan SC, Nadon R, Housman DE, et al. mTORC1 promotes survival through translational control of Mcl-1. Proceedings of the National Academy of Sciences of the United States of America. 2008; 105:10853-10858.

62. Warr MR, Acoca S, Liu Z, Germain M, Watson M, Blanchette M, Wing SS, Shore GC. BH3-ligand regulates access of MCL-1 to its E3 ligase. Federation of European Biochemical Societies letters. 2005; 579:5603-5608.

63. Gomez-Bougie P, Menoret E, Juin P, Dousset C, PellatDeceunynck C, Amiot M. Noxa controls Mule-dependent Mcl-1 ubiquitination through the regulation of the Mcl-1/ USP9X interaction. Biochemical and biophysical research communications. 2011; 413:460-464.

64. Czabotar PE, Lee EF, van Delft MF, Day CL, Smith BJ, Huang DC, Fairlie WD, Hinds MG, Colman PM. Structural 
insights into the degradation of Mcl-1 induced by BH3 domains. Proceedings of the National Academy of Sciences of the United States of America. 2007; 104:6217-6222.

65. Hikita H, Takehara T, Shimizu S, Kodama T, Shigekawa M, Iwase K, Hosui A, Miyagi T, Tatsumi T, Ishida H, Li W, Kanto T, Hiramatsu N, et al. The Bcl-xL inhibitor, ABT737, efficiently induces apoptosis and suppresses growth of hepatoma cells in combination with sorafenib. Hepatology. 2010; 52:1310-1321.

66. Lee SY, Lee SH, Yang EJ, Kim EK, Kim JK, Shin DY, Cho ML. Metformin Ameliorates Inflammatory Bowel Disease by Suppression of the STAT3 Signaling Pathway and Regulation of the between Th17/Treg Balance. PloS one. 2015; 10:e0135858.

67. Tan XL, Bhattacharyya KK, Dutta SK, Bamlet WR, Rabe KG, Wang E, Smyrk TC, Oberg AL, Petersen GM, Mukhopadhyay D. Metformin suppresses pancreatic tumor growth with inhibition of NFkappaB/STAT3 inflammatory signaling. Pancreas. 2015; 44:636-647.
68. Deng XS, Wang S, Deng A, Liu B, Edgerton SM, Lind SE, Wahdan-Alaswad R, Thor AD. Metformin targets Stat3 to inhibit cell growth and induce apoptosis in triple-negative breast cancers. Cell cycle. 2012; 11:367-376.

69. Ding Q, Huo L, Yang JY, Xia W, Wei Y, Liao Y, Chang CJ, Yang Y, Lai CC, Lee DF, Yen CJ, Chen YJ, Hsu JM, et al. Down-regulation of myeloid cell leukemia-1 through inhibiting Erk/Pin 1 pathway by sorafenib facilitates chemosensitization in breast cancer. Cancer research. 2008; 68:6109-6117.

70. Lee DH, Kim DW, Lee HC, Lee JH, Lee TH. Phenethyl isothiocyanate sensitizes glioma cells to TRAILinduced apoptosis. Biochemical and biophysical research communications. 2014; 446:815-821. 